\title{
Contributions on Gargaphia (Heteroptera, Tingidae) systematics: redescriptions of two South American species with considerations on the status of $G$. inca
}

\author{
Marcus Guidoti \\ Programa de Pós Graduação em Biologia Animal, Universidade Federal do Rio Grande do Sul (UFRGS), Av. Bento Gonçalves, 9500, Prédio 43.435, 91501-970, Porto Alegre, RS, Brazil. \\ (marcus.guidoti@gmail.com)
}

\begin{abstract}
Gargaphia inca Monte, 1943 was synonymized with G. opima Drake, 1931 without any declared reasons. Gargaphia inca is known only from its type location (Satipo, Peru), and G. opima from Colombia (Villavencio) and Peru (Cam. Del Pichis, type-locality), in addition to the new records here presented, including the first record for Ecuador. Both species are redescribed, and the status of $G$. inca is revisited and raised from synonymy. Illustrations of some of the most remarkable differences between these taxa are provided, as well as dorsal habitus images. Discussions on the genus systematic status and this nomenclatural act are presented.
\end{abstract}

KEY WORDS. Gargaphia opima, lacebugs, Neotropical, new records, synonym.

\begin{abstract}
RESUMO. Contribuições sobre a sistemática de Gargaphia (Heteroptera, Tingidae): redescrições de duas espécies sul-americanas com considerações sobre o status de G. inca. Gargaphia inca Monte, 1943 foi sinonimizada com G. opima Drake, 1931 sem que as razões para este ato nomenclatural fossem apresentadas. Gargaphia inca é conhecida apenas da sua localidade-tipo (Satipo, Peru), enquanto G. opima foi registrada para a Colômbia (Villavencio) e Peru (Cam. Del Pichis), além dos novos registros aqui apresentados, que incluem o primeiro registro da espécie para o Equador. Ambas espécies foram redescritas, e G. inca foi revalidada. Illustrações de alguns dos caracteres diferenciais foram disponibilizadas, assim como fotos do habitus dorsal. Discussões sobre o status do gênero e o ato nomenclatural aqui proposto são apresentadas.
\end{abstract}

PALAVRAS-CHAVE. Gargaphia opima, Neotropical, novos registros, percevejos de renda, sinônimo.

Gargaphia Stål, 1873 is a Neotropical genus of Tingidae (Hemiptera, Heteroptera) comprising about 70 species. Accordingly to HuRD (1946), this genus may be characterized by the interrupted rostral channel. Gargaphia inca Monte, 1943 was described after the study of nine specimens collected in Satipo (Peru), and until nowadays this is the unique locality reported for this species. Gargaphia opima Drake, 1931 was also described based on individuals collected in Peru, but it was later reported for Colombia and Bolivia (Drake \& Hambleton, 1945; DRAKE \& RUHOFF, 1965). Host plant record is available only for G. opima [Canavalia ensiformis (L.) DC. - DRAKE \& HAMBLETON, 1945]. Biological, ethological or nymphal data are unknown for these species.

DraKe \& Hambleton (1945) proposed G. inca as junior synonym of G. opima without any justification. Monte (1947) replied to this nomenclatural act providing solid arguments and precise illustrations of both species, suggesting that the act was a mistake. After a recent visit to both author's collections, and the access to some of their personal communications, it was clear that Drake and Hambleton never accessed the typematerial of G. inca. In addition, MonTE (1947) declared that he had studied G. opima type-material. In this same contribution, MonTe (1947) highlighted textual parts of the original description of both species illustrating the remarkable differences between these species. Regardless Monte's efforts to revalidate $G$. inca, the world catalog published (DRAKE \& RUHOFF, 1965) still considered the species as a junior synonym of G. opima. Thus, I reassessed this taxonomic issue and redescribed both species, revalidating $G$. inca and providing new distributions records for G. opima, including the first record for Ecuador.

\section{MATERIAL AND METHODS}

The specimens studied are deposited in the National Museum of Natural History (NMNH Smithsonian Institution, Washington, D.C., United States) and Museu Nacional (MNRJ - Universidade Federal do Rio de Janeiro, Rio de Janeiro, RJ, Brazil). Photographs were taken with a digital camera attached to a stereomicroscope. Drawings were made from pictures, and vectorial image files were produced. Measurements were taken for six specimens per species in Image $\mathrm{J}$ software, after calibration for each specimen. They are given in millimeters and represented as follows: mean (lower - higher values). Terminology of DRAKE \& Davis (1960) was followed. Toponyms of the species occurrence data were updated in Global Gazetteer. Geographic coordinates were obtained with Google Earth, and the map was built in Quantum Gis (v. 1.8.0).

\section{RESULTS}

Gargaphia opima Drake, 1931

(Figs 1, 3, 4, 6)

Gargaphia opima Drake, 1931:513; Monte, 1947:232, figs 2, 4; DRAKE \& RUHOFF, 1965:229.

Redescription. Head dark brown, short. Five light 
brown cephalic spines; occipitals close to the head surface, divergent; median and frontal pair slightly erected, almost half of the size of the occipitals; frontal pair slightly convergent. Antenae long, slender, pilose; scape and pedicel dark brown, almost black, distiflagellomere darker; basiflagellomere light brown; scape two and a half longer than pedicel; basiflagellomere at least five times longer than scape and two times than distiflagellomere. Bucculae closed in front; rostrum brown, darker at apex; reaching the posterior region of mesosternum. Pronotum black at the disc, distal part of the posterior projection white, tricarinate. Hood small, faintly projected over the head. Paranota biseriate, strongly reflexed, much at middle; slightly constricted before the middle in some specimens; areolas large, rectangular. Carina foliaceous, edge light brown; areolated, entirely uniseriate, areolas usually larger than the areolas of paranota; median carina slightly higher than lateral carina (Fig. 4), becoming obsolete posteriorly; lateral carina parallel at the disc, slightly convergent in the pronotal posterior projection, extending from the base of the hood to the white area of the pronotal posterior projection. Rostral channel interrupted, sternal laminae with small subrectangular areolas; prosternal laminae straight, parallel; mesosternal laminae straight, divergent; metasternal laminae closed anteriorly, strongly curved, forming an angle, convergent posteriorly; concave in the remainder (Fig. 6). Hemelytra large, twice the lenght of the abdomen; edge dark brown, hyaline costal and sutural area, subcostal and discoidal area blackish, whitish in the young adult; discoidal always whitish at the very posterior edge; transversal blackish nervures in costal, area at the median level of the discoidal area, and before sutural area; this with at least two darker nervures, following the end of subcostal area. Costal area with two areolas anteriorly, three areolas after that, and four in the widest part; areolas larger towards the posterior region, there slightly smaller than those of sutural area. Subcostal area biseriate, areolas subequal in size to those on the pronotal posterior projection. Discoidal area almost one third the lenght of the hemelytra; five to six areolas in the widest part, at middle; areolas in general slightly smaller than those of the subcostal area. Legs light brown, tarsi blackish, almost black; mesocoxae closer to metacoxae than procoxae. Abdomen dark brown to black, lighter in young adults.

Measurements. Scape length, 0.18 (0.17 - 0.19); pedicel length, 0.08 (0.07-0.08); basiflagellomere length, 0.80 (0.72 - 0.84); distiflagellomere length, 0.38 (0.36 $0.40)$; discoidal area length, $0.61(0.53-0.72)$; total body length without wings, $1.42(1.33-1.51)$; total body length, 2.09 (1.98 - 2.27); total body width, $0.90(0.83-1.06)$.

Material examined. COLOMBIA, Caldas: San José, 1 specimen, V.1946, E. J. Hambleton col. (NMNH); Meta: Restrepo, 5 specimens, 2.X.1965 (new record, NMNH); Villavicencio, 4 specimens, 3.XI.1944, E. J. Hambleton col. (NMNH); (920m), 1 specimen, 11.III.1955 (NMNH); Pachaquiaro, 20 specimens, 4.IX.1965, C. Peralonso col. (new record, NMNH). ECUADOR, Zamora Chinchipe: Zamora, 14 specimens, 1-5.VI.1976, A. Langley et al. col. (NMNH);

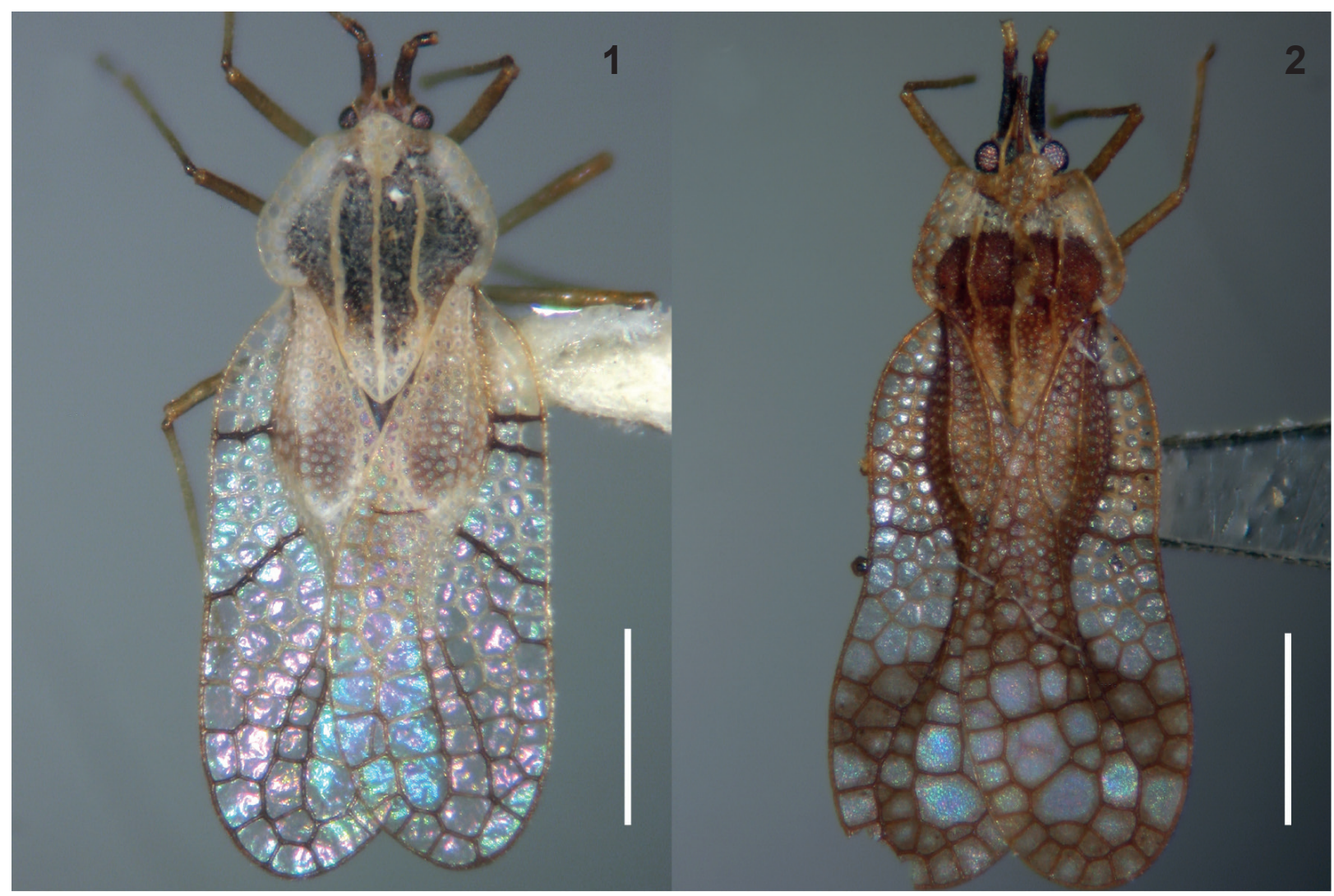

Figs 1, 2. Dorsal habitus of Gargaphia opima Drake, 1931 and G. inca Monte, 1943: 1, G. opima; 2, G. inca. Scale bar: 0.5 mm. 


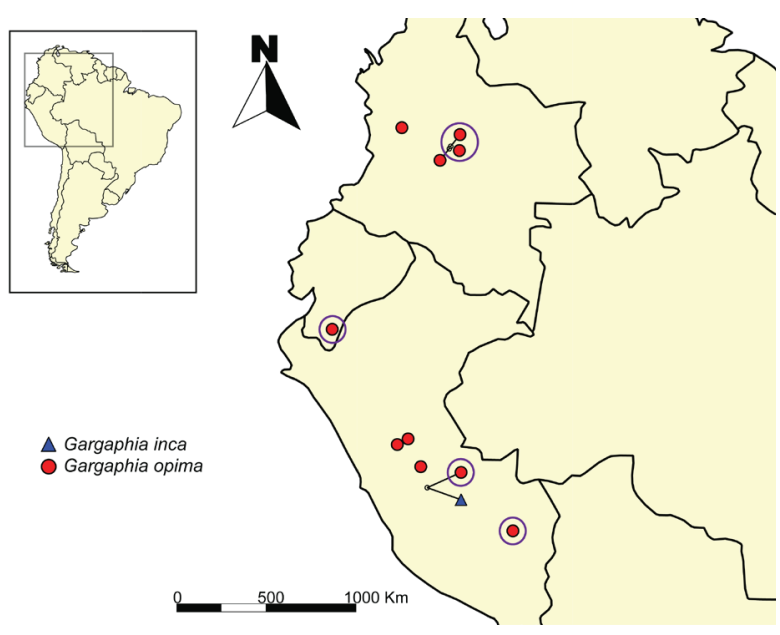

Fig. 3. Distribution of Gargaphia opima Drake, 1931 and G. inca Monte, 1943. Circles indicate new distribution records.

Zamora, 18 specimens, 10.VI.1965, A. Langley et al. col. (new record, NMNH); Zamora, 1 specimen, 12.VI.1965, A. Langley et al. col. (NMNH). PERU, Ucayali: Aguaytia, 22 specimens, 6.IX.1944, E. J. Hambleton col. (NMNH); Huánuco: Tingo Maria, 15 specimens, V.1946, E. J. Hambleton col. (NMNH); Pasco: Miriatiriani (Cam. del Pichis), 1 specimen, 9.VII.1920, Bradley col. (MNRJ); Junín: Satipo, 2 specimens, 10.X.1941, P. Paprzycki col. (new record, NMNH); Cusco: Quince Mil, 8 specimens, X.1962 (new record, NMNH).

\section{Gargaphia inca Monte, 1943 sp. reval.}

(Figs 2, 3, 5, 7)

Gargaphia inca MONTE, 1943:105, fig. 1; 1947:232, figs 1, 3. Gargaphia opima DRAKE \& HAMBLETON, 1945:365; DRAKE \& RUHOFF, 1965:229.

Redescription. Head dark brown, short. Five long cephalic spines; occipital pair light brown, median and frontal pair darker; occipitals close to the head surface, convergent; median and frontal pair erected, same size or longer than occipitals; frontal pair slightly convergent, the longest. Antennae long, slender, almost glabrous; scape dark brown, four times the lenght of pedicel; pedicel and basiflagellomere yellowish; distiflagellomere light brown. Bucculae closed in front, projected forwards; rostrum light brown, tip darker; reaching the posterior region of mesosternum. Pronotum brown at the disc, almost entirely white at the posterior projection, tricarinate. Hood strongly projected over the head. Paranota triseriate anteriorly, biseriate from the middle to the posterior region; uniformly reflexed, slightly constricted before the middle; areolas large, subquadrate or subrectangular, subequal in size between the rows. Carina foliaceous, edge light brown to whitish; areolate, the lateral entirely uniseriate, the median biseriate at the widest part; areolas of lateral carina as those of paranota, outer row of areolas of the median carina rectangular, twice as large as the areolas of lateral carina and paranota; median carina conspicuously higher than lateral carina at the middle (Fig. 5) and with a black stain; lateral carina parallel on the disc, slightly convergent on the pronotal posterior projection, extending from the base of the hood to the white part of the pronotal posterior projection. Rostral channel interrupted, sternal laminae with small subrounded areolas; prosternal laminae convex; mesosternal laminae slightly concave anteriorly, parallel; metasternal laminae in contact anteriorly, convergent posteriorly, strongly concave, anteriorly and posteriorly closed with a straight laminae (Fig. 7). Hemelytra large, twice the lenght of the abdomen; edge light brown, hyaline costal area, with brown stain at the posterior region; subcostal area dark brown, discoidal area lighter; sutural area with brown stain at the rounded tip; three perpendicular dark brown nervures in costal area, anteriorly, posteriorly and after discoidal area. Costal area with two areolas anteriorly, three areolas after that, and five areolas in the widest part; areolas slightly larger towards the posterior region, but always smaller than the areolas of the sutural area. Subcostal area quadriseriate, areolas subequal in size to those in the pronotal posterior projection and discoidal area. Discoidal area more than one third the lenght of the hemelytra; four areolas in the widest part, at middle. Legs light brown, slightly darker than basiflagellomere, tarsi even darker, but still light brown; mesocoxae closer to metacoxae than procoxae. Abdomen black or strongly blackish

Measurements. Scape length, $0.22(0.20-0.23)$; pedicel length, 0.07 (0.07-0.08); discoidal area length, $0.50(0.48-0.53)$; total body length without wings, 1.34 $(1.30-1.39)$; total body length, $2.08(2.02-2.21)$; total body width, $0.74(0.72-0.78)$.

Material examined. PERU, Junín: Satipo, type and alotype, IV.1942, P. Paprzycki col. (MNRJ); Satipo, 6 specimens, 23.VIII.1949, P. Paprzycki col. (NMNH).

4

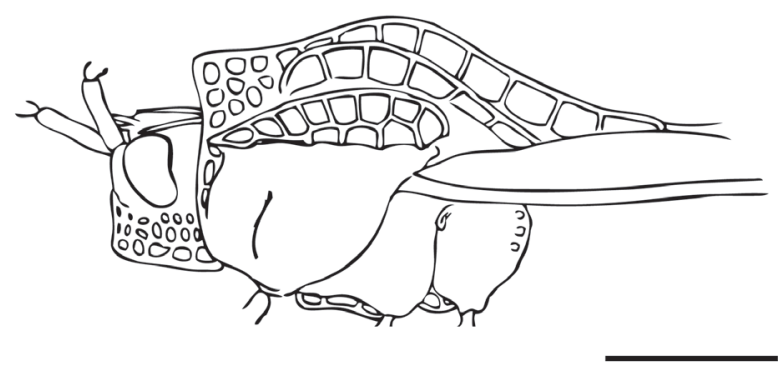

5

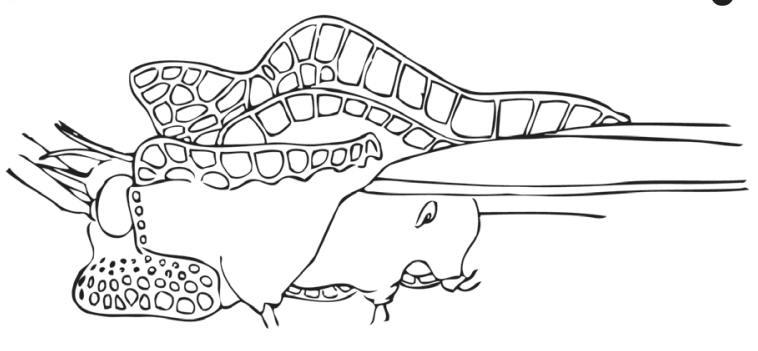

Figs 4, 5. Lateral view: 3, Gargaphia opima Drake, 1931; 4, Gargaphia inca Monte, 1943. Scale bar: $0.25 \mathrm{~mm}$ (modified from MonTE, 1947). 


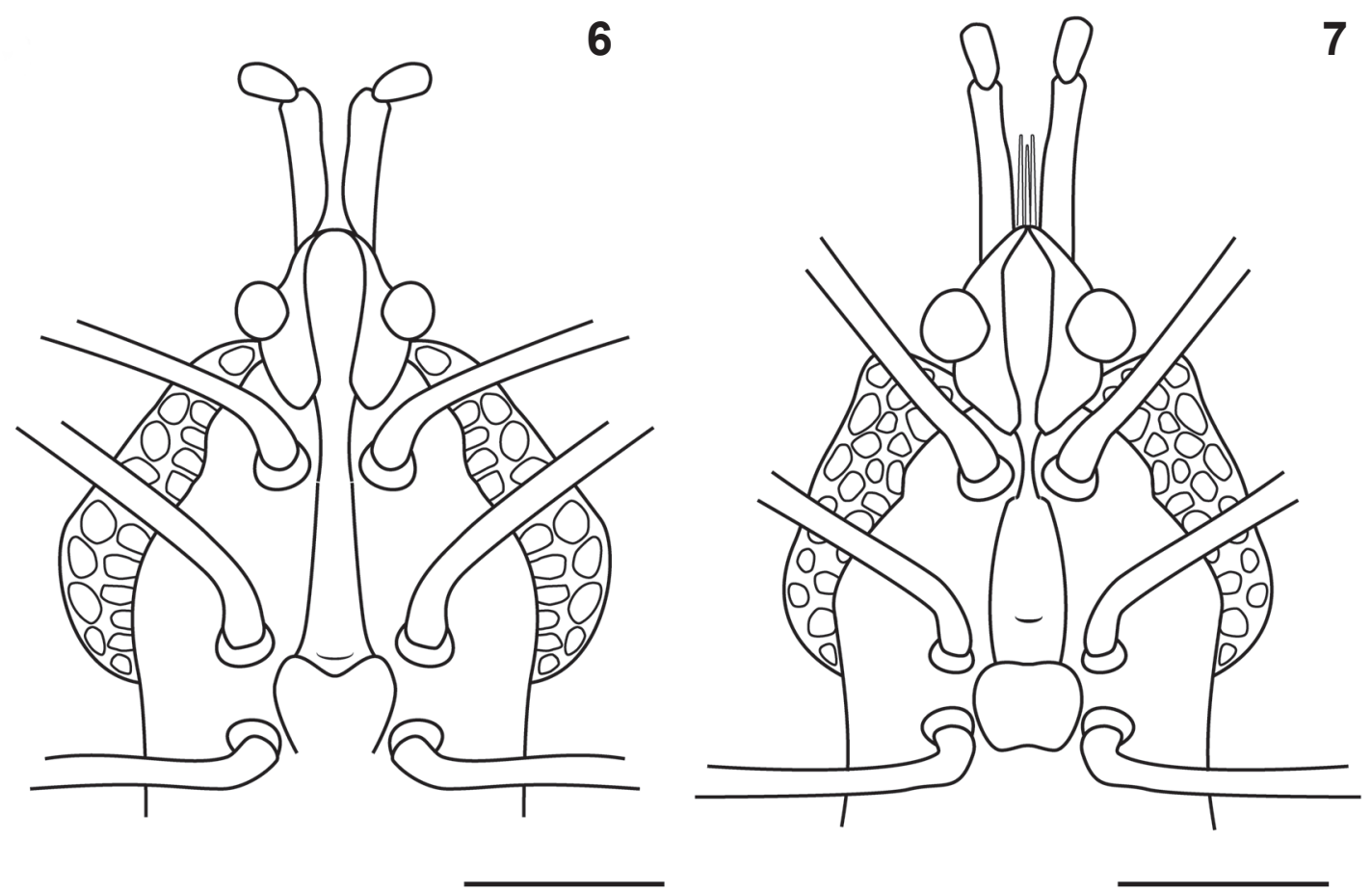

Fig. 6, 7. Rostrum channel: 6, Gargaphia opima Drake, 1931; 7, Gargaphia inca Monte, 1943. Scale bar: 0.25 mm.

\section{DISCUSSION}

Besides the differences already observed by MonTe (1947), several others could be emphasized: size and position of the cephalic spines, longer and more erected in $G$. inca; projection of the hood, much more pronunciated in $G$. inca; projection of the bucculae in front of the clypeous in G. inca; shape of sternal laminae, specially the metasternal laminae and the color pattern of the hemelytra. In addition to these recently differences here reported, the elevation of the median carina, the shape and number of rows of cells of the paranota, and the number of rows of areolas of the subcostal area are the most remarkable differences between these species. Monte (1943) postulated that the median carina of $G$. inca distinguishes the species from all its congeners. Due to aforementioned characters, it is strongly unlikely that both group of specimens assigned to each name be consider the same species.

Along with the sympatry presented by these species of Gargaphia, G. opima was also reported to four other localities in Peru, as well as four in Colombia and one in Ecuador. The report of this species in Zamora (Ecuador) is the first record in this country. The occurrence in Satipo and Quince Mil (Peru) as well as Pachaquiaro and Restrepo (Colombia) are also first records in these localities. Only two specimens of G. opima sampled in Satipo were found in NMNH, both collected in 1941, before the release of Drake \& Ruhoff's catalog. However, this record was not published so far. The presence of such specimens from the type-locality of $G$. inca allied with the non-access to the $G$. inca type-material, could be the reason for the synonymy proposed by DRAKE \& HAMBLETON (1945). The specimen(s) voucher(s) of the record for G. opima in Bolivia (Drake \& RuHofF, 1965) was not found in the Drake's collection (NMNH) and was never reported elsewhere, therefore, it was not represented in the map here provided. Gargaphia inca remains known only for the type-locality in Satipo (Peru).

Monte and Drake had a personal conflict in the late 1930's, which affected the access to type-material. This battle could be accessed through personal letters between the authors, and between them and the Dr. José Cândido de Mello Carvalho. Several taxonomic acts were taken due these disagreements, and accordingly to Monte (1947), the issue here addressed was only one of them. Leptopharsa Stål, 1873, Phymacysta Monte, 1942 and Teleonemia Costa, 1864 are some of the other genera that played an important role in the author's disagreements. Both authors were incredible productive at that time, and several Neotropical species of Tingidae were described during the conflict. Recently, Montemayor \& Dellapé (2010) reassessed the issue with other species of Gargaphia (G. subpilosa Berg, 1879; G. bergi Monte, 1940 and G. penningtoni Drake, 1928), which were also target of arguments between Drake and Monte. However, much more is still needed in order to minimize the influence of that rivalry on the Tingidae systematics. Therefore, all of these disagreements should be reassessed and a special attention should be paid to the Neotropical taxa described during that time. 
Acknowledgements. I would like thank Aline Barcellos (Museu de Ciências Naturais, Fundação Zoobotânica do Rio Grande do Sul) for the fruitful comments on the first version of this manuscript. Also, I would like thank Thomas Henry for welcome me in the NMNH and encouragements for publishing this contribution. To Luiz Costa, for welcome me in the MNRJ and allow access to Monte's collection. To the Smithsonian Institution for the Short-Term Visitor Program awarded to me, which allowed my visit to the Drake's collection. To $\mathrm{CNPq}$, for the M.Sc. fellowship.

\section{REFERENCES}

Berg, C. 1879. Hemiptera Argentina. Anales de la Sociedad Científica Argentina 7(1):41-47.

Drake, C. J. 1931. The Cornell University Entomological Expedition to South America, 1919 and 1920, scientific results, number 5, Hemiptera-Tingitidae. Annals of the Entomological Society of America 24(3):510-514

Drake, C. J. \& DavIS, N. T. 1960. The Morphology, Phylogeny, and Higher Classification of the Family Tingidae, Including the Description of a New Genus and Species of the Subfamily Vianaidinae (Hemiptera: Heteroptera). Entomologica Americana 39:1-100.
Drake, C. J. \& Hambleton, E. J. 1945. Concerning Neotropical Tingitidae (Hemiptera). Journal of the Washington Academy of Sciences 35(11):356-367.

Drake, C. J. \& Ruhoff, F. A. 1965. Lacebugs of the World: A Catalog (Hemiptera: Tingidae). United States National Museum Bulletin 243:1-634.

HURD, M. P. 1946. Generic classification of north american Tingoidea (Hemiptera-Heteroptera). Iowa State College Journal of Science 20(4):429-492.

Monte, O. 1940. Notas sobre Gargaphia subpilosa Berg (HemipteraTingitidae). Arquivos do Instituto Biológico 11:301-308. 1942. Critica sobre alguns generos e especies de Tingitideos. Papéis Avulsos do Departamento de Zoologia 2(6):103-115. 1943. Sobre Tingitídeos do Perú. Revista Brasileira de Biologia 3(1): 105-108.

1947. Notas sinonímicas. Papéis Avulsos do Departamento de Zoologia 8(19):231-237.

Montemayor, S. I. \& Dellapé, P. M. 2010. On the identity of Gargaphia subpilosa Berg, 1879, G. bergi Monte, 1940 and G. penningtoni Drake, 1928 (Insecta, Hemiptera, Heteroptera, Tingidae), with the description of immatures of G. bergi. Zoosystema 32(1):155-162. 